\title{
Evaluation of the radiopacity of selected calcium-silicate root canal sealers
}

\section{Ocena pochtaniania promieniowania rentgenowskiego przez wybrane krzemianowo-wapniowe uszczelniacze kanatowe}

\author{
Przemysław Reszka', Katarzyna Grocholewicz², Agnieszka Droździk², Mariusz Lipski® ${ }^{\bowtie}$ \\ 1 Prywatna Specjalistyczna Praktyka Stomatologiczna w Koszalinie, ul. Traugutta 31/4, 75-569 Koszalin \\ Private Specialist Dental Practice in Koszalin \\ ${ }^{2}$ Pomorski Uniwersytet Medyczny w Szczecinie, Zakład Stomatologii Zintegrowanej, al. Powstańców Wlkp. 72, 70-111 Szczecin \\ Pomeranian Medical University in Szczecin, Department of Integrated Dentistry \\ ${ }^{3}$ Pomorski Uniwersytet Medyczny w Szczecinie, Katedra i Zakład Stomatologii Zachowawczej Przedklinicznej i Endodoncji Przedklinicznej, al. Powstańców Wlkp. 72, \\ 70-111 Szczecin \\ Pomeranian Medical University in Szczecin, Department of Preclinical Conservative Dentistry and Preclinical Endodontics \\ \lipam@pum.edu.pl
}

\begin{abstract}
Introduction: International standards require adequate radiopacity of root canal filling materials to distinguish them from natural structures, such as tooth tissues, and to allow evaluation of the quality of the root canal filling.

The aim of this in vitro study was to assess the radiopacity of selected calcium-silicate root canal sealers compared with the resin-based AH Plus root canal sealer.

Materials and methods: The study included 6 root canal sealers: BioRoot RCS, GuttaFlow bioseal, MTA Fillapex, Total Fill BC Sealer, Well-Root ST and AH Plus. Six disc-shaped samples were prepared from all analysed materials (4 $\mathrm{mm}$ in diameter and $1 \mathrm{~mm}$ thick) and analysed using a digital radiography technique and aluminium step wedges (1.5-15 mm thick) as a standard reference.
\end{abstract}

\begin{abstract}
ABSTRAKT
Wstęp: Międzynarodowe normy wymagają, by materiały stosowane do wypełniania kanałów korzeniowych pochłaniały promieniowanie rentgenowskie w stopniu pozwalającym na ich odróżnienie od tkanek zęba, gwarantując tym samym ocenę jakości wypełnienia kanału.

Celem pracy była ocena in vitro pochłaniania promieniowania rentgenowskiego przez wybrane krzemianowo-wapniowe uszczelniacze kanałowe w porównaniu z uszczelniaczem na bazie żywic AH Plus. Materiały i metody: Ocenie poddano 6 uszczelniaczy: BioRoot RCS, GuttaFlow bioseal, MTA Fillapex, Total Fill BC Sealer, Well-Root ST i AH Plus. Ogółem z każdego materiału wykonano po 6 próbek w kształcie krążka (średnica $4 \mathrm{~mm}$ i wysokość $1 \mathrm{~mm}$ ). Następnie wykonano badanie radiograficzne przygotowanych próbek wraz ze schodkowym klinem aluminiowym (schodki o wysokości 1,5-15 mm). Na podstawie uzyskanych obrazów określano stopień pochłaniania promieni rentgenowskich
\end{abstract}

\section{INTRODUCTION}

Despite significant progress in dental material science, guttapercha is still the most commonly used material for the final filling of root canals [1]. It is usually used in a cold filling method to close the root canals, as a single gutta-percha cone or many condensed cones using a suitable instrument, although, warm filling methods (vertical condensation using a warm downpack device, injection technique, root canal filling
The radiopacity was determined using computer image analysis. The data was statistically analysed using a Tukey's range test. Results: All root canal sealers showed radiopacity at least corresponding to the $3 \mathrm{~mm}$ aluminium step wedge. AH Plus (13.23 $\mathrm{mm} \mathrm{Al}$ ) showed the highest radiopacity, followed by Total Fill BC Sealer (7.93 mm Al), Well-Root ST (7.12 mm Al), BioRoot RCS (5.93 $\mathrm{mm} \mathrm{Al})$ and GuttaFlow bioseal (5.08 mm Al). MTA Fillapex (3.02 $\mathrm{mm} \mathrm{Al}$ ) showed the lowest radiopacity.

Conclusions: Although the evaluated root canal sealers show different radiopacities, all the materials met the criteria laid down by the International Organization of Standardization. Keywords: root canal filling materials; silicates; epoxy resins; radiopacity.

przez poszczególne uszczelniacze. Oceny statystycznej dokonano testem Tukeya.

Wyniki: Wszystkie oceniane uszczelniacze kanałowe pochłaniały promieniowanie rentgenowskie co najmniej w takim stopniu jak aluminium o grubości $3 \mathrm{~mm}$. W największym stopniu promieniowanie pochłaniała pasta AH Plus $(13,23 \mathrm{~mm} \mathrm{Al})$, a w dalszej kolejności: Total Fill BC Sealer(7,93 mm Al), Well-Root ST (7,12 $\mathrm{mm} \mathrm{Al}$ ), BioRoot RCS (5,93 mm Al) i GuttaFlow bioseal (5,08 $\mathrm{mm} \mathrm{Al).W}$ najmniejszym stopniu promieniowanie X pochłaniał uszczelniacz MTA Fillapex (3,02 mm Al).

Wniosek: Pomimo zróżnicowanych zdolności pochłaniania promieniowania rentgenowskiego, wszystkie oceniane uszczelniacze kanałowe spełniają wymagania Międzynarodowej Organizacji Normalizacyjnej.

Słowa kluczowe: materiały do wypełniania kanałów korzeniowych; krzemiany; żywice epoksydowe; pochłanianie promieniowania rentgenowskiego.

\section{WSTĘP}

Pomimo znacznego postępu w zakresie materiałoznawstwa stomatologicznego nadal powszechnie stosowanym materiałem do ostatecznego wypełniania kanałów korzeniowych jest gutaperka [1]. Zazwyczaj używana jest do zamknięcia kanałów na zimno metodą pojedynczego ćwieka, względnie wielu ćwieków kondensowanych za pomocą odpowiedniego narzędzia. Od pewnego czasu jednak dużą popularnością cieszą się także 
with a gutta-percha coated carrier) are gaining popularity $[1$ $2,3]$. The gutta-percha alone, even thermoplasticized, will not guarantee adequate obturation. Therefore, it should be used with sealers $[1,4]$.

Currently, dentists have access to many different root canal sealers. The most common are epoxy resin-based materials $\mathrm{AH}$ Plus, TopSeal, Adseal), however, root canal sealers based on calcium hydroxide (e.g. Sealapex, Apexit) and oxide-zinc-eugenol (e.g. Tubleaseal, Caryosan) are still popular. Glass ionomer cements are no longer used (e.g. Ketac Endo, Endion) mainly due to difficulties in removal during retreatment; as well as pastes containing strong bactericides due to their toxicity and high susceptibility to dissolution in body fluids (e.g. Endoform, Rezoform) [1, 4, 5].

Among the many desirable attributes of root canal sealers are biocompatibility, the ability to maintain constant volume both during and after the setting stage, and good adhesion to the dentin and gutta-percha. Furthermore, root canal sealers must not dissolve in body fluids, shrink or cause discolouration to tooth tissues. From the clinician's point of view, the materials should also feature a specific radiopacity to distinguish them from tooth tissues $[1,4]$. A standard issued by the International Organization for Standardization - ISO 6876: 2012 states that a $1 \mathrm{~mm}$ thick sample of root canal sealer must show a radiopacity corresponding to a $3 \mathrm{~mm}$ thick aluminum plate [6]. To meet this requirement, the manufacturers had added a contrast medium in the form of silver, but now mostly with barium, lanthanum, tungsten or zirconium $[1,4,7]$.

A recently analysed group of materials for root canal filling that scored well for biocompatibility includes sealers containing calcium silicates - a main components of mineral trioxide aggregate (MTA) commonly used in endodontics. In Englishlanguage literature the materials are referred to as bioceramic root canal sealers. Along with a biocompatibility specific for calcium silicate-based materials, they also show anti-bacterial and anti-fungal properties $[7,8,9]$. Bioceramic root canal sealers not only contain biocompatible calcium silicates, but also bioactive phosphates and calcium hydroxide. The common additives to improve contrast are bismuth or zirconium oxide, and less frequently iodine or silver compounds $[7,10]$.

The aim of the study was to evaluate the radiopacity of bioceramic sealers compared to the gold standard - AH Plus - a synthetic resin-based material.

\section{MATERIALS AND METHODS}

The following bioceramic root canal sealers were assessed:

- BioRoot RCS (Septodont, France),

- GuttaFlow bioseal (Coltene/Whaledent, Switzerland),

- MTA Fillapex (Angelus, Brazil),

- Total Fill BC Sealer (FKG, Switzerland),

- Well-Root ST (Vericom, Korea),

- AH Plus (Dentsply, DeTrey, Germiany) - the most commonly used epoxy resin-based sealer. metody wypełniania kanałów na ciepło (kondensacja pionowa z użyciem gorącego upychacza, technika iniekcyjna, metoda wypełniania kanału nośnikiem pokrytym warstwą gutaperki) [1, $2,3]$. Sama gutaperka, nawet po uplastycznieniu, nie zapewnia niestety wypełnieniu odpowiedniej szczelności. W związku z tym należy ją stosować w połączeniu z uszczelniaczami [1, 4].

Obecnie lekarze dentyści mają do dyspozycji wiele uszczelniaczy kanałowych. Najczęściej stosowane są materiały, których podstawowy składnik stanowi żywica epoksydowa (pasta AH Plus, TopSeal, Adseal), ale nadal z pewnym zainteresowaniem spotykają się uszczelniacze wodorotlenkowo-wapniowe (np. Sealapex, Apexit) oraz tlenkowo-cynkowo-eugenolowe (np. Tubleaseal, Caryosan). Nie stosuje się już natomiast cementów szkło-jonomerowych (np. Ketac Endo, Endion), głównie ze względu na trudności w ich usunięciu podczas powtórnego leczenia endodontycznego, oraz past zawierających silne środki bakteriobójcze w związku z ich toksycznością i dużą podatnością na rozpuszczanie w płynach ustrojowych (np. Endoform, Rezoform) [1, 4, 5].

Wśród wielu pożądanych cech uszczelniaczy kanałowych wymienia się m.in.: biozgodność, zachowanie stałej objętości zarówno podczas wiązania, jak i po stwardnieniu oraz dobre przylegania do zębiny kanałowej i gutaperki. Od uszczelniaczy kanałowych wymaga się ponadto, by nie rozpuszczały się w kontakcie z płynami ustrojowymi, nie kurczyły się, a także nie przebarwiały tkanek zęba. Ważne z punktu widzenia klinicysty jest również, aby miały odpowiednią zdolność pochłaniania promieni X i dzięki temu były widoczne na zdjęciu rentgenowskim w stopniu pozwalającym na ich odróżnienie od tkanek zęba [1, 4]. Norma Międzynarodowej Organizacji Normalizacyjnej (International Organization for Standardization - ISO) - ISO 6876:2012 stanowi, że uszczelniacze kanałowe w postaci próbki o grubości $1 \mathrm{~mm}$ powinny pochłaniać promieniowanie rentgenowskie przynajmniej w takim stopniu jak płytka aluminiowa o grubości $3 \mathrm{~mm}$ [6]. Aby spełnić ten warunek, producenci uszczelniaczy przed laty dodawali do nich środki kontrastujące w postaci srebra, a obecnie wykorzystują przede wszystkim związki baru, lantanu, wolframu oraz cyrkonu $[1,4,7]$.

Najnowszą grupą materiałów do ostatecznego wypełniania kanałów, bardzo dobrze ocenianych pod względem biozgodności, są uszczelniacze zawierające krzemiany wapnia, stanowiące podstawowy składnik stosowanego od wielu lat w endodoncji mineral trioxide aggregate (MTA). W anglosaskim piśmiennictwie określane są one mianem uszczelniaczy bioceramicznych (bioceramic root canal sealers). Poza biokomatybilnością typową dla materiałów na bazie krzemianów wapnia charakteryzują się one także właściwościami przeciwbakteryjnymi i przeciwgrzybiczymi [7, 8, 9]. Uszczelniacze bioceramiczne, oprócz biozgodnych krzemianów wapnia, dość często zawierają również bioaktywne fosforany i wodorotlenek wapnia. Do tych materiałów, w celu zapewnienia kontrastowości, dodawany jest zazwyczaj tlenek bizmutu lub cyrkonu, a rzadziej związki jodu lub srebro $[7,10]$.

Celem pracy była ocena pochłaniania promieni rentgenowskich przez uszczelniacze bioceramiczne w porównaniu ze złotym standardem - preparatem na bazie żywic syntetycznych, pastą AH Plus. 
The exact chemical composition of the sealers is given in Table 1.

To obtain disc-shaped material samples (4 $\mathrm{mm}$ in diameter and $1 \mathrm{~mm}$ high), 7 holes with a diameter of $4 \mathrm{~mm}$ were made in a $20 \mathrm{~mm} \times 40 \mathrm{~mm} \times 1 \mathrm{~mm}$ plastic plate. The holes in the plate were filled with the analysed materials (with a slight excess) and pressed with a cover glass. The plate was placed in a closed container at high humidity and left in a thermostat for a week for the sealers to set. In total, 6 samples of each material were prepared. The samples and an aluminium step wedge (Pro-RTG 21 Steps/Model: 02-305, Pro-Project, Poland) were positioned on a recording plate and a radiograph was taken using a Gendex Expert DC X-ray system (Gendex Dental

\section{MATERIAtY I METODY}

Ocenie poddano następujące uszczelniacze kanałowe bioceramiczne:

- BioRoot RCS (Septodont, Francja),

- GuttaFlow bioseal (Coltène/Whaledent, Szwajcaria),

- MTA Fillapex (Angelus, Brazylia),

- Total Fill BC Sealer (FKG, Szwajcaria),

- Well-Root ST (Vericom, Korea),

- AH Plus (Dentsply, DeTrey, Niemcy) - najpowszechniej stosowany uszczelniacz na bazie żywic epoksydowych.

Dokładny skład chemiczny uszczelniaczy przedstawiono w tabeli 1.

TABLE 1. Chemical composition of the analysed root canal sealers (data from the manufacturers' brochures)

TABELA 1. Skład chemiczny ocenianych uszczelniaczy kanałowych (dane z ulotek producentów)

\begin{tabular}{ll}
$\begin{array}{l}\text { Name (manufacturer) } \\
\text { Nazwa (producent) }\end{array}$ & \multicolumn{1}{c}{$\begin{array}{c}\text { Form/packing } \\
\text { Postać/konfekcjonowanie }\end{array}$} \\
\hline $\begin{array}{l}\text { BioRoot RCS } \\
\text { (Septodont, France/ } \\
\text { Francja) }\end{array}$ & $\begin{array}{l}\text { powder and liquid / glass bottle and } \\
\text { plastic ampoule } \\
\text { proszek i płyn / szklana buteleczka } \\
\text { i ampułka z tworzywa sztucznego }\end{array}$ \\
\hline $\begin{array}{l}\text { GuttaFlow bioseal } \\
\text { (Coltėne/Whaledent, } \\
\text { Switzerland/Szwajcaria }\end{array}$ & $\begin{array}{l}\text { two pastes in double syringe with } \\
\text { automixing applicator }\end{array}$ \\
& z samomieszającym aplikatorem \\
MTA Fillapex & two pastes in double syringe with \\
(Angelus, Brazil/ & automixing applicator \\
Brazylia) & $\begin{array}{l}\text { dwie pasty w podwójnej strzykawce } \\
\text { z samomieszającym aplikatorem }\end{array}$
\end{tabular}

Total Fill BC Sealer (FKG, single paste in syringe

Switzerland/Szwajcaria) jedna pasta w strzykawce
Chemical composition

Skład chemiczny

powder: tricalcium silicate, zirconium dioxide, povidone liquid: water, calcium chloride, and polycarboxylate

proszek: trójkrzemian wapnia, dwutlenek cyrkonu, powidon płyn: woda, chlorek wapnia, polikarboksylan

pulverized gutta-percha, polydimethylsiloxane,

silver, zirconium dioxide, platinum, pigment, and bioactive ceramic glass

sproszkowana gutaperka, polydimetylosiloksan, platyna, dwutlenek cyrkonu, srebro, barwnik, bioaktywne szkło ceramiczne

paste A: salicylate resin, bismuth oxide, and silica paste B: silicon dioxide, titanium dioxide, resin, MTA

pasta A: żywica salicylanowa, tlenek bizmutu, krzemionka pasta B: dwutlenek krzemu, dwutlenek tytanu, żywice, MTA

zirconium oxide, calcium silicates, monobasic calcium phosphate, calcium hydroxide, filler and thickening agents

tlenek cyrkonu, krzemiany wapnia, fosforan jednozasadowy wapnia, wodorotlenek wapnia, wypełniacz i substancje zagęszczające

\begin{tabular}{lll}
\hline Well-Root ST & single paste in syringe & zirconium oxide, calcium silicate, filler, thickening agents \\
(Vericom, Korea) & jedna pasta w strzykawce & tlenek cyrkonu, krzemian wapnia, wypełniacz, substancje zagęszczające
\end{tabular}

AH Plus

(Dentsply, DeTrey, Germany/Niemcy) two pastes in tubes for manual mixing

dwie pasty w tubkach, wymagają ręcznego zmieszania paste A: bisfenol-A epoxy resin, bisfenol-F epoxy resin, calcium tungstate, zirconium oxide, silicone oxide, iron oxide

paste B: dibenzyl diamine, adamantane amine, TCD-diamine, calcium tungstate, zirconium oxide, silicone oxide, silicone oil

pasta A: bisfenol-A żywica epoksydowa, bisfenol-F żywica epoksydowa, wolframian wapnia, tlenek cyrkonowy, tlenek krzemowy, tlenek żelazowy pasta B: diamina dibenzylowa, aminoadamantan, diamina tricyklodekanu, wolframian wapnia, tlenek cyrkonowy, tlenek krzemu, olej silikonowy
Systems, USA). The samples were exposed to X-ray radiation at a distance of $30 \mathrm{~cm}(65 \mathrm{mV}$ and $7 \mathrm{~mA})$. The resulting image was exported to a Digora Optime Soredex system (Soredex, Finland) and analysed. For each sealer, 5 optical density measurements were carried out using a linear function. The study included the most frequently recurring value. The wedge (1.5-15 mm steps) density was also measured. Similar to the sealers, a linear optical density was measured 5 times for each step, also including the most frequently recurring value.
W celu uzyskania próbek materiałów w kształcie krążka o średnicy $4 \mathrm{~mm}$ i wysokości $1 \mathrm{~mm}$ wykonano w płytce z tworzywa sztucznego o wymiarach $20 \mathrm{~mm}$ x $40 \mathrm{~mm}$ x $1 \mathrm{~mm}$ siedem otworów o średnicy $4 \mathrm{~mm}$. Otwory w płytce wypełniono z lekkim nadmiarem ocenianymi materiałami, a następnie dociśnięto je szkiełkiem przykrywkowym. Płytkę umieszczono w zamkniętym naczyniu o dużej wilgotności i pozostawiono w cieplarce na tydzień w celu związania uszczelniaczy. Ogółem z każdego materiału wykonano po 6 próbek. W dalszej kolejności 
A cubic polynomial was determined by regression analysis and used to approximate the calibration curve, attributing the abstract numbers to the aluminium thickness. The results were statistically evaluated using post hoc Tukey's range test at a significance level of $p<0.05$.

\section{RESULTS}

Figure 1 shows the average contrast values of each sealer expressed against the aluminium reference standard thickness. All the analysed sealers showed radiopacity at least corresponding to a $3 \mathrm{~mm}$ aluminium step, meeting the ISO standard requirement.

AH Plus (13.23 mm Al) showed the highest radiopacity. Its contrast was significantly different from the other analysed sealers $(\mathrm{p}<0.0001)$. Total Fill BC Sealer and Well-Root ST (7.93 mm Al and $7.12 \mathrm{~mm} \mathrm{Al}$, respectively; $p=0.2942$ ) as well as BioRoot RCS and GuttaFlow bioseal $(5.93 \mathrm{~mm} \mathrm{Al}$ and $5.08 \mathrm{~mm} \mathrm{Al}$, respectively; $\mathrm{p}=0.2547$ ) showed the lowest radiopacity, while the values recorded for BioRoot RCS and GuttaFlow bioseal sealers were significantly lower compared to Total Fill BC Sealer $(p<0.0003$ and $p<0.0001$, respectively) and Well-Root ST ( $p=0.0435$ and $p=0.0002$, respectively). MTA Fillapex (3.02 $\mathrm{mm} \mathrm{Al}$ ) showed the lowest radiopacity. The statistical analysis showed significant differences between MTA Fillapex and the other sealers ( $p<0.002$ compared to GuttaFlow bioseal and $\mathrm{p}<0.001 \mathrm{com}-$ pared to the other sealers).

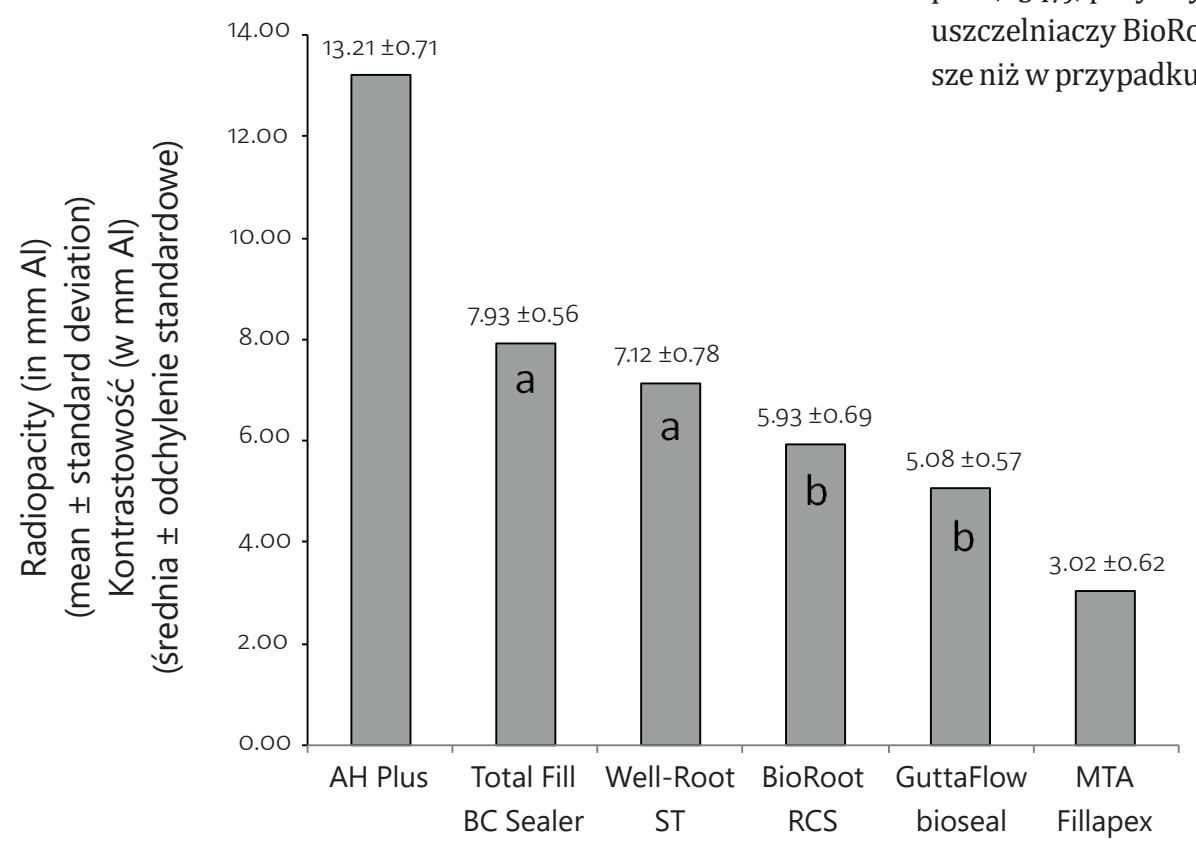

próbki wraz z aluminiowym klinem schodkowym (Pro-RTG 21 Steps/Model: 02-305, Pro-Project, Polska) ułożono na płytce rejestrującej i wykonano zdjęcie z użyciem aparatu rentgenowskiego Gendex Expert DC (Gendex Dental Systems, USA). Ekspozycji dokonywano z odległości $30 \mathrm{~cm}$ (65 mV i $7 \mathrm{~mA}$ ). Następnie uzyskany obraz eksportowano do systemu Digora Optime Soredex (Soredex, Finlandia) i poddano ocenie. W przypadku każdego uszczelniacza dokonano 5 pomiarów gęstości optycznej przy użyciu funkcji liniowej. W badaniu uwzględniano najczęściej powtarzającą się wartość. Pomiarów gęstości dokonano również w przypadku klina dla schodków o wysokości 1,5-15 mm. Podobnie jak w przypadku uszczelniaczy, dla każdej wysokości schodka 5-krotnie dokonano pomiaru liniowego gęstości optycznej, uwzględniając również najczęściej powtarzającą się wartość. Analizą regresji wyznaczono wielomian 3. stopnia, który zastosowano do aproksymacji krzywej kalibracyjnej przyporządkowującej wartości niemianowane dla grubości aluminium. Uzyskane wyniki poddano ocenie statystycznej testem post hoc Tukeya. Za poziom istotności przyjęto $\mathrm{p}<0,05$.

\section{WYNIKI}

Średnie wartości kontrastowości poszczególnych uszczelniaczy wyrażonych w grubościach aluminium przedstawiono na rycinie 1. Wszystkie poddane ocenie uszczelniacze pochłaniały promienie rentgenowskie co najmniej w takim stopniu, jak 3 mm schodek aluminiowy, czyli spełniały normę ISO.

Promieniowanie rentgenowskie najintensywniej pochłaniała pasta AH Plus (13,23 mm Al). Jej kontrastowość różniła się istotnie od kontrastowości pozostałych ocenianych uszczelniaczy ( $p<0,0001)$. W mniejszym stopniu promieniowanie rentgenowskie pochłaniały uszczelniacze Total Fill BC Sealer i Well-Root ST (odpowiednio 7,93 mm Al i 7,12 mm Al; p = 0,2942) oraz BioRoot RCS i GuttaFlow bioseal (odpowiednio 5,93 mm Al i 5,08 mm Al; $\mathrm{p}=0$,2547), przy czym wartości zarejestrowane w przypadku uszczelniaczy BioRoot RCS i GuttaFlow bioseal były istotnie niższe niż w przypadku preparatu Total Fill BC Sealer (odpowiednio 


\section{DISCUSSION}

The aim of the study was to assess the radiopacity of bioceramic sealers compared to the commonly used AH Plus root canal sealer. All the analysed bioceramic sealers, with the exception of MTA Fillapex, show a relatively good radiopacity, which in each case was still significantly lower than that observed for AH Plus paste. MTA Fillapex sealer showed low contrast properties by generating an X-ray image with an optical density equivalent to the density of a $3.02 \mathrm{~mm}$ thick aluminium plate, which may result in poor visibility in clinical conditions. As per Shah et al. [11], any material barely meeting the standard requirements, i.e. with radiopacity corresponding to a $3 \mathrm{~mm}$ aluminium plate, will probably not be clearly visible in the image due to the superposition of various anatomical structures on the root, including an alveolar process or soft tissue. The quantity of the sealer is also a key factor in obtaining good visibility. Although the bioceramic sealers are most often recommended to be used with a single gutta-percha cone (relatively high sealer ratio in the root canal filler), in the root apex, the layer may be thin enough and barely meet the standard requirements, and may not be clearly visible in the radiographs.

According to the manufacturer, MTA Fillapex shows excellent contrast, which has been verified in different studies Table $2[12,13,14,15,16,17,18,19,20,21,22,23,24,25,26]$. The highest values were reported by Marciano et al. $(9.4 \mathrm{~mm}$ Al) [23], although other authors also reported good radiopacity within the range of 6.73 to $7.17 \mathrm{~mm} \mathrm{Al}[12,13,14,15,16$, $17,18,20,24,26]$. Viapiana et al. [19] reported contrast corresponding to a $3.9 \mathrm{~mm} \mathrm{Al}$, and Lee et al. [25] reported its limit value at $3.01 \mathrm{~mm} \mathrm{Al}$, consistent with the observations made in this study. In the cited studies, along with the evaluation of MTA Fillapex contrast, the radiopacity of commonly used AH Plus root canal sealer was also analysed. Viapiana et al. [19] reported the radiopacity of AH Plus to be almost 5-times higher compared to MTA Fillapex sealer, Lee et al. [25] found a 3 -fold difference, Siboni et al. [26] reported a 1.5-fold difference, whereas, Silva et al. [18] and Prüllage et al. [22] did not show any difference in contrast. The author's own study showed a 4-fold difference in contrast between MTA Fillapex sealer and AH Plus sealer. The differences in methods used do not justify the discrepancies between the studies, despite slight differences in the methods used by the authors. Table 2 shows the results of radiopacity for other analysed bioceramic sealers. Despite some differences in the contrasts of individual materials discussed in the literature, good radiopacity was observed for all sealers, i.e. AH Plus paste and materials: BioRoot RCS, GuttaFlow bioseal, Total Fill BC Sealer and Well-Root ST which indicates that even in adverse conditions (e.g. superposition of thick anatomical structures over the root canal image), the sealers were clearly visible in the radiographs [11].

As noted earlier, all the sealers analysed in the study meet the ISO standard requirements, although to a different extent. Since the author's own research was carried out under identical $\mathrm{p}<0,0003$ i $\mathrm{p}<0,0001$ ) oraz uszczelniacza Well-Root ST (odpowiednio $\mathrm{p}=0,0435 \mathrm{i} \mathrm{p}<0,0002$ ). W najmniejszym stopniu promieniowanie rentgenowskie pochłaniał uszczelniacz MTA Fillapex (3,02 mm Al). Analiza statystyczna wykazała istotne różnice pomiędzy tym preparatem a pozostałymi uszczelniaczami ( $\mathrm{p}<0,002 \mathrm{w}$ porównaniu z preparatem GuttaFlow bioseal i $\mathrm{p}<0,001 \mathrm{w}$ porównaniu z pozostałymi uszczelniaczami).

\section{DYSKUSJA}

Celem przeprowadzonego badania była ocena pochłaniania promieni rentgenowskich przez uszczelniacze bioceramiczne w porównaniu ze stosowaną od wielu lat pastą AH Plus. Wszystkie poddane ocenie uszczelniacze bioceramiczne, z wyjątkiem MTA Fillapex, charakteryzowały się względnie dobrą zdolnością pochłaniania promieni X, choć zdecydowanie gorszą niż pasta AH Plus. Natomiast uszczelniacz MTA Fillapex wykazywał słabe właściwości kontrastujące, generując na rentgenogramie obraz o gęstości optycznej równoważnej gęstości płytki aluminiowej o grubości 3,02 mm, co może skutkować w warunkach klinicznych jego słabą widocznością na zdjęciu rentgenowskim. Zgodnie bowiem z opinią Shaha i wsp. [11] materiał spełniający zaledwie normę, tj. pochłaniający promieniowanie rentgenowskie w takim samym stopniu jak płytka aluminiowa o grubości $3 \mathrm{~mm}$, prawdopodobnie nie będzie wyraźnie dostrzegalny na zdjęciu z powodu nakładania się na korzenie zębów różnych struktur anatomicznych, takich jak kość wyrostka zębodołowego czy tkanki miękkie. Nie bez znaczenia dla uzyskania dobrej widoczności uszczelniacza jest również jego ilość. Wprawdzie uszczelniacze bioceramiczne zaleca się najczęściej stosować w połączeniu z pojedynczym ćwiekiem gutaperkowym (stosunkowo duży udział uszczelniacza w materiale wypełniającym kanał), to jednak w części wierzchołkowej kanału ich warstwa może być na tyle cienka, że uszczelniacze spełniające zaledwie normę mogą nie być widoczne na rentgenogramach.

Preparat MTA Fillapex wg producenta charakteryzuje się doskonałą kontrastowością, co zostało potwierdzone licznymi badaniami - tabela $2[12,13,14,15,16,17,18,19,20,21,22$, $23,24,25,26]$. Najwyższe wartości zarejestrowali Marciano i wsp. (9,4 mm Al) [23], choć i pozostali autorzy odnotowali dobrą zdolność pochłaniania promieni X w zakresie 6,73-7,17 mm Al przez ten preparat $[12,13,14,15,16,17,18,20,24,26]$. Natomiast Viapiana i wsp. [19] wykazali w przypadku tego uszczelniacza kontrastowość odpowiadającą 3,9 mm Al, a Lee i wsp. [25] zarejestrowali jej graniczną wartość (3,01 mm Al), co jest zgodne z obserwacjami poczynionymi w badaniu własnym. W cytowanych badaniach równocześnie z oceną kontrastowości materiału MTA Fillapex opisano również zdolność do pochłaniania promienni X przez powszechnie stosowaną pastę AH Plus. Viapiana i wsp. [19] stwierdził prawie 5-krotnie większe zdolności pochłaniania promieni X przez pastę AH Plus niż przez uszczelniacz MTA Fillapex, Lee i wsp. [25] -3-krotnie, Siboni i wsp. [26] - 1,5-krotnie, a Silva i wsp. [18] oraz Prüllage i wsp. [22] nie wykazali różnic w kontrastowości. 
conditions, the observed differences between the materials are certainly due to the amount and type of contrast medium used. AH Plus root canal sealer, which shows the best contrast, contains zirconium and iron oxides and calcium tungstate as contrast media. On the other hand, good visibility in the Total Fill BC Sealer and Well-Root ST radiographs can be attributed to the zirconium oxide content. Zirconium oxides are also used in BioRoot RCS and GuttaFlow bioseal, although the good visibility can be attributed to povidone (BioRoot RCS) and silver (GuttaFlow bioseal) content. However, MTA Fillapex sealer, showing the lowest contrast, contains bismuth oxide and MTA $[7,17,18,19]$.

In the study, a digital radiograph was used to evaluate the sealer contrasts using a densitometric measurement function. This method is commonly used to evaluate the contrast of dental materials, it is quicker and simpler than conventional optical density analysis methods $[13,25,26,27,28,29]$. However,
Natomiast w badaniach własnych kontrastowość uszczelniacza MTA Fillapex okazała się 4-krotnie mniejsza niż pasty AH Plus. Biorąc pod uwagę ten fakt, nie ma możliwości tłumaczenia różnicami w metodyce rozbieżności pomiędzy cytowanymi badaniami, choć można dostrzec pewne rozbieżności w metodach zastosowanych przez poszczególnych autorów. W tabeli 2 zawarto także wyniki dotyczące pochłaniania promieni $\mathrm{X}$ przez pozostałe uszczelniacze bioceramiczne oceniane $w$ badaniu własnym. Mimo pewnych różnic w kontrastowościach poszczególnych materiałów prezentowanych w piśmiennictwie, w przypadku wszystkich uszczelniaczy, tj. pasty AH Plus oraz materiałów: BioRoot RCS, GuttaFlow bioseal, Total Fill BC Sealer i Well-Root ST, zaobserwowano dość dobrą zdolność do pochłaniania promieni X. To sugeruje, że nawet w niesprzyjających warunkach (np. w sytuacji nakładania się grubych struktur anatomicznych na obraz wypełnionego kanału) uszczelniacze te będą wyraźnie dostrzegalne na zdjęciu rentgenowskim [11].

TABLE 2. The data reported by the studies for root canal sealers analysed in the author's own study (expressed as an aluminium wedge thickness in mm) [12, $13,14,15,16,17,18,19,20,21,22,23,24,25,26]$

TABELA 2. Zestawienie wyników badań dotyczących kontrastowości uszczelniaczy kanałowych ocenianych w badaniu własnym (w mm klina aluminiowego) $[12,13,14,15,16,17,18,19,20,21,22,23,24,25,26]$

\begin{tabular}{|c|c|c|c|c|c|c|}
\hline \multirow{2}{*}{$\begin{array}{l}\text { Authors (year) } \\
\text { Autorzy (rok) }\end{array}$} & \multicolumn{6}{|c|}{ Root canal sealer / Uszczelniacz } \\
\hline & AH Plus & MTA Fillapex & BioRoot RCS & Well-Root ST & $\begin{array}{l}\text { GuttaFlow } \\
\text { bioseal }\end{array}$ & $\begin{array}{l}\text { Total Fill BC } \\
\text { Sealer }\end{array}$ \\
\hline Tagger and Katz (2003) / Tagger i Katz (2003) & 9.00 & & & & & \\
\hline $\begin{array}{l}\text { Carvalho-Junior et al. (2007) / Carvalho-Junior } \\
\text { i wsp. (2007) }\end{array}$ & 11.20 & & & & & \\
\hline $\begin{array}{l}\text { Tanomaru-Filho et al. (2007) / Tanomaru-Filho } \\
\text { i wsp. (2007) }\end{array}$ & 9.80 & & & & & \\
\hline Flores et al. (2011) / Flores i wsp. (2011) & 6.00 & & & & & \\
\hline Pawińska et al. (2011) / Pawińska i wsp. (2011) & 6.83 & & & & & \\
\hline Candeiro et al. (2012) / Candeiro i wsp. (2012) & 6.94 & & & & & \\
\hline Silva et al. (2013) / Silva i wsp. (2013) & 8.59 & 7.06 & & & & \\
\hline Viapiana et al. (2014) / Viapiana i wsp. (2014) & 18.40 & 3.90 & & & & \\
\hline Hrab et al. (2017) / Hrab i wsp. (2017) & & & & & & 4.00 \\
\hline Khalil et al. (2016) / Khalil i wsp. (2016) & 18.40 & & 8.30 & & & \\
\hline Prüllage et al. (2016) / Prüllage i wsp. (2016) & 6.85 & 6.73 & 6.85 & & & \\
\hline Marciano et al. (2016) / Marciano i wsp. (2016) & & 9.40 & & & & \\
\hline Gandolfi et al. (2016) / Gandolfi i wsp. (2016) & & 7.17 & & & 5.62 & \\
\hline Lee et al. (2017) / Lee i wsp. (2017) & 10.00 & 3.01 & & & & \\
\hline Siboni et al. (2017) / Siboni i wsp. (2017) & 11.80 & 7.10 & 5.20 & & & \\
\hline Reszka et al. (2019) / Reszka i wsp. (2019) & 13.23 & 3.02 & 5.93 & 7.12 & 5.08 & 7.93 \\
\hline
\end{tabular}


to obtain reliable test results, similar to the results obtained when evaluating contrast using conventional images and a densitometer, an aluminium step wedge reference standard must be used [29]. The reference standard was used in this study, and allowed us to express the radiopacity of the analysed materials as an aluminium plate thickness in $\mathrm{mm}$, and not in absolute values, for which the ISO has not yet created any standards.

\section{CONCLUSIONS}

1. All evaluated root canal sealers meet the requirements of the ISO in terms of radiopacity.

2. The contrast showed by the analysed bioceramic sealers is satisfactory, however, the limit radiopacity of MTA Fillapex raises some concerns.

3. The radiopacity of calcium-silicate root canal sealers is diverse.

4. AH Plus root canal sealer shows much higher contrast compared to bioceramic sealers.

\section{REFERENCES / PIŚMIENNICTWO}

1. Whitworth J. Methods of filling root canals: principles and practices. Endod Topics 2005;12:2-24.

2. Lipski M. Gutaperka jako materiał do wypełniania kanałów korzeniowych. Mag Stomatol 2003;13(7-8):21-4.

3. Palatyńska-Ulatowska A, Pawlicka H. Najczęściej stosowane termiczne metody wypełniania kanałów korzeniowych - przegląd piśmiennictwa. Dent Med Probl 2006;43(3):327-32.

4. Ørstavik D. Materials used for root canal obturation: technical, biological and clinical testing. Endod Topics 2005;12:25-38.

5. Tyagi S, Mishra P, Tyagi P. Evolution of root canal sealers: An insight story. Eur J Gen Dent 2013;2(3);199-218.

6. International Organization for Standardization. International Standard ISO6876:2012. Dental root canal sealing materials. Geneva: International Organization for Standardization; 2012.

7. Bansode PV, Pathak SD, Wandhane MB, Chavan PV. A review of bioceramic sealers in endodontics. J Dent Med Sci 2018;17:82-6.

8. Shakya VK, Gupta P, Tikku AP, Pathak AK, Chandra A, Yadav RK, et al. An in vitro evaluation of antimicrobial efficacy and flow characteristics for AH Plus, MTA Fillapex, CRCS and Gutta Flow 2 root canal sealer. J Clin Diagn Res 2016;10(8):ZC104-8.

9. AlShwaimi E, Bogari D, Ajaj R, Al-Shahrani S, Almas K, Majeed A. In vitro antimicrobial effectiveness of root canal sealers against Enterococcus faecalis: A systematic review. J Endod 2016;42(11):1588-97.

10. Ozcan E, Yula E, Arslanoğlu Z, Inci M. Antifungal activity of several root canal sealers against Candida albicans. Acta Odontol Scand 2013;71(6):1481-5.

11. Shah PM, Sidhu SK, Chong BS, Ford TR. Radiopacity of resin-modified glass ionomer liners and bases. J Prosthet Dent 1997;77(3):239-42.

12. Tagger M, Katz A. Radiopacity of endodontic sealers: development of a new method for direct measurement. J Endod 2003;29(11):751-5.

13. Carvalho-Junior JR, Correr-Sobrinho L, Correr AB, Sinhoreti MA, Consani $\mathrm{S}$, Sousa-Neto MD. Radiopacity of root filling materials using digital radiography. Int Endod J 2007;40(7):514-20.
Jak już wcześniej zaznaczono, wszystkie oceniane w obecnym badaniu uszczelniacze spełniały normę ISO, chociaż w różnym zakresie. Ponieważ badania własne wykonano w identycznych warunkach, zaobserwowane różnice pomiędzy materiałami wynikają z całą pewnością zarówno z ilości, jak i rodzaju użytego w nich kontrastu. Pasta AH Plus, która okazała się najlepiej kontrastującym uszczelniaczem, zawiera w swoim składzie kontrast w postaci tlenków cyrkonu i żelaza oraz wolframianu wapnia. Natomiast za widoczność na zdjęciach rentgenowskich uszczelniaczy Total Fill BC Sealer i Well-Root odpowiadają prawdopodobnie wyłącznie tlenki cyrkonu. Są one obecne również w składzie BioRoot RCS i GuttaFlow bioseal, choć dobrą widoczność tych uszczelniaczy w obrazie RTG można także tłumaczyć zawartością powidonu (BioRoot RCS) i srebra (GuttaFlow bioseal). Natomiast uszczelniacz MTA Fillapex, który okazał się najsłabiej kontrastowym materiałem, zawiera w swoim składzie tlenek bizmutu oraz MTA $[7,17,18,19]$.

W badaniu własnym do oceny kontrastowości uszczelniaczy uży to radiografu cyfrowego, posługując się funkcją pomiaru densytometrycznego. Metoda ta jest powszechnie stosowana w celu oceny kontrastowości materiałów stomatologicznych, głównie ze względu na to, że jest szybsza i prostsza niż konwencjonalny sposób oceny gęstości optycznej $[13,25,26,27,28$, 29]. Aby jednak wyniki badania były miarodajne, podobnie jak podczas oceny kontrastowości z użyciem konwencjonalnych zdjęć i densytometru, wymaga użycia wzorca w postaci aluminiowego klina schodkowego [29]. W badaniu własnym użyto takiego wzorca, co pozwoliło podać zdolność pochłaniania promieni $X$ ocenianych materiałów w równoważnych im grubościach płytki aluminiowej (wartości w mm), a nie w niemianowanych jednostkach liczbowych, dla których ISO jak dotąd nie stworzyła norm.

\section{WNIOSKI}

1. Wszystkie oceniane uszczelniacze kanałowe spełniają wymogi ISO dotyczące widoczności w badaniu rentgenowskim.

2. Kontrastowość ocenianych uszczelniaczy bioceramicznych jest zadowalająca; zastrzeżenia budzi graniczna zdolność materiału MTA Fillapex do pochłaniana promieniowania X.

3. Zdolność pochłaniania promieniowania rentgenowskiego przez uszczelniacze kanałowe na bazie krzemianów wapnia jest zróżnicowana.

4. Pasta AH Plus charakteryzuje się zdecydowanie większą kontrastowością niż porównywane z nią uszczelniacze bioceramiczne. 
14. Tanomaru-Filho M, Jorge EG, Guerreiro Tanomaru JM, Gonçalves M. Radiopacity evaluation of new root canal filling materials by digitalization of images. J Endod 2007;33(3):249-51.

15. Flores DS, Rached FJ Jr, Versiani MA, Guedes DF, Sousa-Neto MD, Pécora JD. Evaluation of physicochemical properties of four root canal sealers. Int Endod J 2011;44(2):126-35.

16. Pawińska M, Różycki J, Łuczaj-Cepowicz E, Kierklo A. Evaluation of the radiopacity of root canal filling materials. J Stoma 2011;64:566-78.

17. Candeiro GT, Correia FC, Duarte MA, Ribeiro-Siqueira DC, Gavini G. Evaluation of radiopacity, $\mathrm{pH}$, release of calcium ions, and flow of a bioceramic root canal sealer. J Endod 2012;38(6):842-5.

18. Silva EJ, Rosa TP, Herrera DR, Jacinto RC, Gomes BP, Zaia AA. Evaluation of cytotoxicity and physicochemical properties of calcium silicate-based endodontic sealer MTA Fillapex. J Endod 2013;39(2):274-7.

19. Viapiana R, Guerreiro-Tanomaru JM, Hungaro-Duarte MA, TanomaruFilho M, Camilleri J. Chemical characterization and bioactivity of epoxy resin and Portland cement-based sealers with niobium and zirconium oxide radiopacifiers. Dent Mater 2014;30(9):1005-20.

20. Hrab D, Chisnoiu AM, Badea ME, Moldovan M, Chisnoiu RM. Comparative radiographic assessment of a new bioceramic-based root canal sealer. Clujul Med 2017;90(2):226-30.

21. Khalil I, Naaman A, Camilleri J. Properties of tricalcium silicate sealers. J Endod 2016;42(10):1529-35.
22. Prüllage RK, Urban K, Schäfer E, Dammaschke T. Material properties of a tricalcium silicate-containing, a mineral trioxide aggregate-containing, and an epoxy resin-based root canal sealer. J Endod 2016;42(12):1784-8.

23. Marciano MA, Duarte MA, Camilleri J. Calcium silicate-based sealers: Assessment of physicochemical properties, porosity and hydration. Dent Mater 2016;32(2):e30-40.

24. Gandolfi MG, Siboni F, Prati C. Properties of a novel polysiloxane-guttapercha calcium silicate-bioglass-containing root canal sealer. Dent Mater 2016;32(5):e113-26.

25. Lee JK, Kwak SW, Ha JH, Lee W, Kim HC. Physicochemical properties of epoxy resin-based and bioceramic-based root canal sealers. Bioinorg Chem Appl 2017;2017:2582849.

26. Siboni F, Taddei P, Zamparini F, Prati C, Gandolfi MG. Properties of BioRoot RCS, a tricalcium silicate endodontic sealer modified with povidone and polycarboxylate. Int Endod J 2017; 50 Suppl 2:e120-36.

27. Lichota D, Lipski M, Woźniak K. An evaluation of the radipacity of root canal sealers. J Stoma 2002;55:14-7.

28. Akcay I, Ilhan B, Dundar N. Comparison of conventional and digital radiography systems with regard to radiopacity of root canal filling materials. Int Endod J 2012;45(8):730-6.

29. Taşdemir T, Yesilyurt C, Yildirim T, Er K. Evaluation of the radiopacity of new root canal paste/sealers by digital radiography. J Endod 2008;34(11):1388-90. 